\title{
RESPON SELEKSI MASSA SECARA TIDAK LANGSUNG TERHADAP DAYA HASIL TANAMAN JAGUNG SELAMA TUJUH SIKLUS DI LAHAN KERING
}

\section{(INDIRECT MASS SELECTION RESPONSE TO THE YIELD AFTER SEVEN CYCLES ON DRY LAND)}

\author{
Sudika $^{1}$, Arya Parwata ${ }^{1}$ dan Soemeinaboedhy ${ }^{2}$ \\ ${ }^{1}$ Program studi Agroekoteknologi, Fakultas Pertanian Universitas Mataram, NTB. \\ 2 Program studi Ilmu Tanah, Fakultas Pertanian Universitas Mataram, NTB. \\ *corresponding author, email: sudikawayanms@gmail.com.
}

Manuscript received: 07-11-2018. Accepted: 19-11-2018

\begin{abstract}
ABSTRAK.
Penelitian ini bertujuan untuk mengetahui besarnya respon seleksi secara tidak langsung terhadap daya hasil tanaman jagung di lahan kering dan mengetahui peningkatan daya hasil akibat tujuh siklus. Metode seleksi yang digunakan adalah seleksi massa dengan pengendalian dan tanpa pengendalian penyerbukan Metode yang digunakan untuk mengurangi efek lingkungan selama seleksi adalah subdevided block, yakni petak seleksi dibagi atas plot-plot kecil. Setiap plot memuat 40 tanaman dan jumlah tanaman terpilih sebanyak 5 persen dalam setiap plot. Rancangan acak kelompok lengkap digunakan untuk pengujian hasil seleksi. Data hasil penelitian dianalisa dengan analisis sidik ragam dan perbedaan antar populasi, diuji dengan beda nyata terkecil pada taraf nyata 5 persen. Rerata respon seleksi per siklus setiap metode, diperoleh dari koefisien regresi linear polinomial antar sifat yang diamati dengan siklus seleksi. Persentase peningkatan daya hasil diperoleh dari selisih populasi siklus ketujuh dikurangi dengan populasi awal dibagi populasi awal. Hasil penelitian menunjukkan bahwa, kemajuan seleksi massa dengan pengendalian penyerbukan dan tanpa pengendalian bersifat linear nyata berturut-turut sebesar 47.88 dan 72.80 g per plot. Peningkatan daya hasil sebesar 43.46 persen diperoleh setelah dilakukan tujuh siklus seleksi massa dengan pengendalian penyerbukan dan 79.21 persen dengan seleksi tanpa pengendalian dibanding populasi awal.
\end{abstract}

Kata kunci: Pengendalian penyerbukan, tanpa pengendalian penyerbukan, populasi awal dan regresi polynomial.

\footnotetext{
ABSTRACT.

The objective of the research is to investigate the selection response indirectly on the corn yield in dry land, and the yield improvements of yield due to seven cycles. The selection method used were mass selection with and without pollination controll. The method used to minimize environmental effect during selection was subdivided block that (subselection block divided into small plots). In each plot, there was 40 plants, and the number plants selected were $5 \%$. Randomized Completely Block Design was used to study the selection result. The data collected were analyzed using
} 
Analysis of Variance, and the difference between populations were tested using Least Significant Difference in $5 \%$ significant level. The average of selection response per cycle every technique used was gained from polynomial regression coefficient among the characters observed with selection cycle The percentage of the corn yield improvement was gained from the difference between the seventh cycle and the base population, and then, substracted by the base population. The result showed that the response indirectly of mass selection with and without pollination controll were significantly linear, and the values were 47.88 and $72.80 \mathrm{~g}$ per plot, respectively. The yield improvements were $43.46 \%$ and $79.21 \%$, respectively.

Keywords: Pollination controll, without pollination controll, base population and polynomial regression

\section{PENDAHULUAN}

Penanaman jagung di Indonesia berada di lahan kering sekitar 60 persen, sehingga diperlukan varietas yang cocok untuk lahan tersebut (Indriani dan Mejaya, 2012). Selain itu, varietas tersebut hendaknya memiliki umur panen tergolong genjah (< 90 hari). Varietas bersari bebas umumnya lebih tahan terhadap cekaman kekeringan. Pembentukan varietas tersebut dapat dilakukan melalui hibridisasi dan seleksi; salah satunya adalah seleksi massa. Seleksi massa dapat dilakukan dengan pengendalian penyerbukan dan tanpa pengendalian penyerbukan (Mejaya, et al., 2010). Seleksi massa dengan pengendalian penyerbukan umumnya memiliki kemajuan seleksi lebih besar dibandingkan dengan tanpa pengendalian; namun sangat tergantung dari keeratan hubungan antar sifat yang diseleksi dengan sifat yang diperbaiki (Soemartono, et al., 1992; Basuki, 2005). Sutresna (2010), memperoleh kemajuan seleksi dengan pengendalian penyerbukan terhadap hasil (berat biji kering pipil per plot) sebesar $2.07 \mathrm{~kg}(44.04 \%)$ selama tiga siklus; lebih tinggi dibanding tanpa pengendalian penyerbukan, yaitu sebesar $1.67 \mathrm{~kg}(33.99 \%)$. Rata-rata kemajuan seleksi dengan pengendalian adalah $14.04 \%$ dan untuk seleksi tanpa pengendalian $11.33 \%$ per siklus. Idris, et al. (2018), memperoleh kemajuan seleksi dengan pengendalian penyerbukan atas dasar tinggi tanaman dan jumlah daun dan tanpa pengendalian atas dasar panjang tongkol, belum menunjukkan perubahan yang nyata dengan populasi awal setelah lima siklus pada jagung lokal Kebo. Harapan kemajuan seleksi harapan tertinggi pada seleksi massa diperoleh pada tinggi tanaman oleh dengan memperhatikan pengaruh blok; sedang tanpa memperhatikan pengaruh blok, diperoleh pada diameter tongkol dan kedudukan tongkol (Rizqi, et al., 2014). Hasil penelitian Elfiani (2015), bahwa tinggi tanaman dapat digunakan untuk kriteria seleksi dalam memperbaiki panjang tongkol dan diameter tongkol pada jagung manis.

Pembentukan varietas unggul untuk lahan kering telah dilakukan; yang diawali dengan pembentukan populasi dasar. Populasi dasar dibentuk dari persilangan antar kultivar lokal dengan varietas unggul dan diperoleh populasi hasil rakitan kultivar lokal (PHRKL). Perbaikan daya hasil PHRKL telah dilakukan selama tujuh siklus menggunakan dua macam seleksi massa secara tidak langsung, yaitu seleksi dengan pengendalian penyerbukan dan tanpa pengendalian penyerbukan. Tinggi tanaman dan jumlah daun digunakan sebagai kriteria seleksi massa dengan pengendalian penyerbukan dan persilangan dilakukan di antara tanaman terpilih. Kriteria seleksi yang digunakan untuk seleksi massa tanpa pengendalian penyerbukan adalah bobot tongkol kering panen. Kedua seleksi massa tersebut secara tidak langsung, akan menyebabkan peningkatan daya hasil. 


\title{
RESPON SELEKSI MASSA SECARA TIDAK LANGSUNG TERHADAP DAYA HASIL TANAMAN JAGUNG SELAMA TUJUH SIKLUS DI LAHAN KERING
}

\section{(INDIRECT MASS SELECTION RESPONSE TO THE YIELD AFTER SEVEN CYCLES ON DRY LAND)}

\author{
Sudika $^{1}$, Arya Parwata ${ }^{1}$ dan Soemeinaboedhy ${ }^{2}$ \\ ${ }^{1}$ Program studi Agroekoteknologi, Fakultas Pertanian Universitas Mataram, NTB. \\ 2 Program studi Ilmu Tanah, Fakultas Pertanian Universitas Mataram, NTB. \\ *corresponding author, email: sudikawayanms@gmail.com.
}

Manuscript received: 07-11-2018. Accepted: 19-11-2018

\begin{abstract}
ABSTRAK.
Penelitian ini bertujuan untuk mengetahui besarnya respon seleksi secara tidak langsung terhadap daya hasil tanaman jagung di lahan kering dan mengetahui peningkatan daya hasil akibat tujuh siklus. Metode seleksi yang digunakan adalah seleksi massa dengan pengendalian dan tanpa pengendalian penyerbukan Metode yang digunakan untuk mengurangi efek lingkungan selama seleksi adalah subdevided block, yakni petak seleksi dibagi atas plot-plot kecil. Setiap plot memuat 40 tanaman dan jumlah tanaman terpilih sebanyak 5 persen dalam setiap plot. Rancangan acak kelompok lengkap digunakan untuk pengujian hasil seleksi. Data hasil penelitian dianalisa dengan analisis sidik ragam dan perbedaan antar populasi, diuji dengan beda nyata terkecil pada taraf nyata 5 persen. Rerata respon seleksi per siklus setiap metode, diperoleh dari koefisien regresi linear polinomial antar sifat yang diamati dengan siklus seleksi. Persentase peningkatan daya hasil diperoleh dari selisih populasi siklus ketujuh dikurangi dengan populasi awal dibagi populasi awal. Hasil penelitian menunjukkan bahwa, kemajuan seleksi massa dengan pengendalian penyerbukan dan tanpa pengendalian bersifat linear nyata berturut-turut sebesar 47.88 dan 72.80 g per plot. Peningkatan daya hasil sebesar 43.46 persen diperoleh setelah dilakukan tujuh siklus seleksi massa dengan pengendalian penyerbukan dan 79.21 persen dengan seleksi tanpa pengendalian dibanding populasi awal.
\end{abstract}

Kata kunci: Pengendalian penyerbukan, tanpa pengendalian penyerbukan, populasi awal dan regresi polynomial.

\footnotetext{
ABSTRACT.

The objective of the research is to investigate the selection response indirectly on the corn yield in dry land, and the yield improvements of yield due to seven cycles. The selection method used were mass selection with and without pollination controll. The method used to minimize environmental effect during selection was subdivided block that (subselection block divided into small plots). In each plot, there was 40 plants, and the number plants selected were $5 \%$. Randomized Completely Block Design was used to study the selection result. The data collected were analyzed using
} 
Mengingat sifat yang diperbaiki tidak sama dengan sifat yang diseleksi, maka respon seleksi sangat tergantung dari keeratan hubungan sifat tersebut (Basuki, 2005). Oleh karena itu, penelitian ini ditujukan untuk mengetahui rata-rata respon seleksi per siklus untuk kedua seleksi massa secara tidak langsung terhadap daya hasil dan mengetahui peningkatan daya hasil setelah dilakukan tujuh siklus seleksi kedua cara seleksi tersebut.

\section{BAHAN DAN METODE}

Metode yang digunakan dalam penelitian ini adalah metode eksperimental dengan seluruh percobaan dilakukan di lahan kering yang berfasilitas pengairan dengan sumur pompa. Metode seleksi untuk perbaikan daya hasil secara tidak langsung menggunakan seleksi massa dengan pengendalian penyerbukan dan tanpa pengendalian penyerbukan. Kedua cara seleksi massa tersebut dilaksanakan selama tujuh siklus di lahan kering. Metode Subdevided block, digunakan untuk mengurangi pengaruh lingkungan pada petak seleksi setiap siklus. Penggunaan metode tersebut dilakukan dengan membagi petak seleksi menjadi 100 plot; masing-masing plot berisi 40 tanaman untuk setiap cara seleksi massa. Seleksi dilakukan dalam setiap plot dengan persentase tanaman terpilih sebanyak 5 persen.

Rancangan yang digunakan dalam pengujian hasil seleksi adalah rancangan acak lengkap kelompok dengan 3 blok dengan jumlah perlakuan sebanyak 16 populasi. Karakterisitik lahan yang digunakan, yakni tekstur geluh pasiran. Pengairan dilakukan setiap 7 hari sekali sejak tanam hingga umur 70 hari. Jarak tanam yang digunakan adalah 20 x $60 \mathrm{~cm}$, satu tanaman per lubang. Setiap populasi dalam setiap blok ditanam sebanyak 2 baris; masing-masing baris memuat 25 tanaman.

Peubah yang diamati meliputi tinggi tanaman, jumlah daun per tanaman, bobot tongkol kering panen per tanaman, panjang tongkol, diameter tongkol, daya hasil ( bobot biji kering pipil per plot) dan bobot 1.000 butir biji.

Data hasil pengamatan dianalisa dengan analisis sidik ragam pada taraf nyata $5 \%$. Rerata populasi, diuji dengan uji beda nyata terkecil (BNT) pada taraf nyata 5\%. Besarnya peningkatan daya hasil, diperoleh dari selisih populasi siklus ketujuh dengan populasi awal (P7DPP - P0/P7TPP - P0). Respon seleksi per siklus setiap cara, diperoleh dari koefisien regresi linear polinomial antara sifat yang diamati dengan siklus seleksi yang dijabarkan dari persamaan linear (Little dan Hills, 1972), sebagai berikut:

$$
\hat{\mathrm{Y}}_{\mathrm{L}}=\overline{\mathrm{Y}}+\left(\mathrm{K}_{2} \mathrm{P}_{1}\right) \mathrm{X}^{\prime}
$$

$$
\mathrm{K}_{2} \mathrm{P}_{1}=\left\{-7\left(\mathrm{Y}_{0 .}\right)-5\left(\mathrm{Y}_{1 .}\right)-3\left(\mathrm{Y}_{2 .}\right)-1\left(\mathrm{Y}_{3 .}\right)+1\left(\mathrm{Y}_{4 .}\right)+3\left(\mathrm{Y}_{5 .}\right)+5\left(\mathrm{Y}_{6 .}\right)+7\left(\mathrm{Y}_{7 .}\right)\right\} /(168 \mathrm{xr})
$$

dengan $\mathrm{K}_{2} \mathrm{P}_{1}=$ koefisien regresi linear polinomial $=$ Respon seleksi per siklus setiap cara; $\mathrm{r}$ $=$ jumlah blok; $\mathrm{Y}_{0 .}, \mathrm{Y}_{1 .}, \mathrm{Y}_{2 .}, \mathrm{Y}_{3 .}, \mathrm{Y}_{4}, \mathrm{Y}_{5 .}, \mathrm{Y}_{6}$ dan $\mathrm{Y}_{7 .}$ berturut-turut merupakan jumlah seluruh blok populasi awal, siklus 1, siklus 2, siklus 3, siklus 4, siklus lima, siklus enam dan populasi siklus 7. Pengujian nyata/tidaknya koefisien regresi linear tersebut menggunakan uji $\mathrm{F}_{0.05}$ dalam analisis ragam dengan memecah sumber ragam populasi menjadi linear dan sisa untuk masing-masing cara seleksi. Heritabilitas arti luas $\left(\mathrm{H}^{2}\right)$, diperoleh dengan rumus:

$$
\mathrm{H}^{2}=\left(\sigma_{\mathrm{g}}^{2} / \sigma_{\mathrm{p}}^{2}\right) \times 100 \%
$$

Selanjutnya dilakukan pengelompokan nilai sesuai dengan pendapat Stanfield (1991), yaitu 50 - 100 , tinggi; $20-<50$; sedang dan rendah apabila nilainya $<20$. 


\section{HASIL DAN PEMBAHASAN}

Hasil

Seleksi massa secara tidak langsung digunakan untuk memperbaiki daya hssil. Seleksi menyebabkan perubahan rerata populasi dan selisihnya disebut respon seleksi. Respon seleksi per siklus untuk dua cara seleksi massa disajikan pada Tabel 1.

Tabel 1. Rata-rata respon seleksi per siklus untuk seleksi dengan pengendalian penyerbukaN (DPP) dan seleksi tanpa pengendalian penyerbukan (TPP) selama tujuh siklus

\begin{tabular}{lcc}
\hline \multirow{2}{*}{ Sifat-sifat yang diamati } & \multicolumn{2}{c}{ Rata-rata Respon seleksi per } \\
& \multicolumn{2}{c}{ siklus } \\
\cline { 2 - 3 } & DPP & TPP \\
\hline Tinggi tanaman (cm) & $1.67 *$ & $1.17 *$ \\
Jumlah daun (helai) & $0.06 *$ & $0.08 *$ \\
Bobot tongkol kering panen per tanaman $(\mathrm{g})$ & $2.42 *$ & $2.86 *$ \\
Panjang tongkol (cm) & $0.06 *$ & $0.12 *$ \\
Diameter tongkol (cm) & $0.02 \mathrm{~ns}$ & $0.02 \mathrm{~ns}$ \\
Bobot biji kering pipil per plot $(\mathrm{g})$ & $47.88 *$ & $72.80 *$ \\
Bobot 1.000 butir biji (g) & $1.50 *$ & $2.50 *$ \\
\hline
\end{tabular}

Keterangan: *) Berbeda nyata pada taraf 5 persen dan ns. tidak berbeda nyata.

Pada Tabel 1 dapat dilihat, bahwa daya hasil (bobot biji kering pipil per plot) memiliki respon seleksi bersifat linear yang nyata, yaitu sebesar 47.88 g.plot ${ }^{-1}$ untuk seleksi dengan pengendalian penyerbukan (DPP) dan 72.80 g. plot $^{-1}$ untuk seleksi tanpa pengendalian penyerbukan (TPP). Bobot tongkol kering panen per tanaman memiliki respon seleksi bersifat linear yang nyata pula untuk kedua cara seleksi massa tersebut. Respon seleksi tinggi tanaman dan jumlah daun per tanaman juga bersifat linear yang nyata. Model garis regresi linear untuk daya hasil disajikan pada Gambar 1.

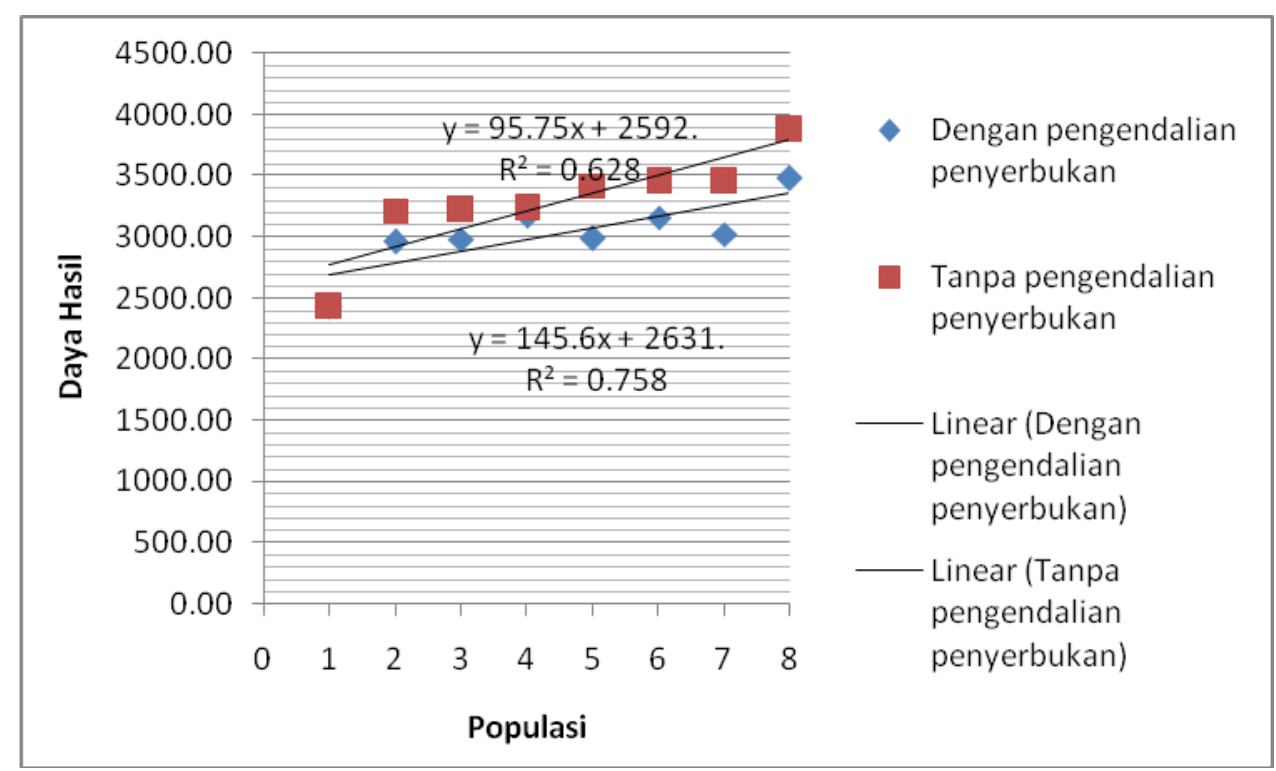

Gambar 1. Grafik linear daya hasil dengan siklus seleksi untuk dua teknik seleksi massa. 
Besarnya Respon seleksi sifat-sifat yang diamati sangat tergantung pula dari keragaman genetik dan heritabilitas. Besarnya keragaman genetik, keragaman fenotip dan nilai heritabilitas arti luas $\left(\mathrm{H}^{2}\right)$ disajikan pada Tabel 2.

Tabel 2. Ragam genotip $\left(\delta^{2}\right)$. ragam fenotip $\left(\delta^{2}\right)$ dan heritabilitas arti luas $\left(\mathrm{H}^{2}\right)$ untuk setiap sifat yang diamati

\begin{tabular}{lccc}
\hline Sifat-sifat yang diamati & $\delta_{\mathrm{g}}^{2}$ & $\delta^{2} \mathrm{p}$ & $\mathrm{H}^{2}(\%)$ \\
\hline Tinggi tanaman & 14.43 & 225.21 & 5.65 \\
Jumlah daun per tanaman & 0.303 & 0.414 & 73.12 \\
Bobot tongkol kering panen per & 115.32 & 288.19 & 40.02 \\
tanaman & & & \\
Panjang tongkol (cm) & 0.14 & 0.44 & 31.82 \\
Diameter tongkol (cm) & 0.01 & 0.02 & 44.51 \\
Daya hasil (bobot biji kering pipil per & 76363.97 & 153496.7 & 49.75 \\
plot) & \multicolumn{3}{c}{} \\
Bobot 1.000 butir biji (g) & 105.55 & 164.43 & 64.19 \\
\end{tabular}

Pada Tabel 2 terlihat, bahwa heritabilitas tergolong tinggi diperoleh pada jumlah daun per tanaman dan bobot 1.000 butir biji. Sifat bobot tongkol kering panen per tanaman, panjang tongkol, diameter tongkol dan daya hasil tergolong sedang dan tinggi tanaman tergolong rendah.

Adanya kemajuan seleksi yang berbeda menyebabkan peningkatan sifat yang berbeda pula, seperti terlihat pada Tabel 3 .

Tabel 3. Rerata seluruh sifat yang diamati untuk setiap perlakuan pada seleksi massa dengan pengendalian dan tanpa pengendalian penyerbukan

\begin{tabular}{|c|c|c|c|c|c|c|c|}
\hline \multirow[t]{2}{*}{ Perlakuan } & \multicolumn{5}{|c|}{ Rerata *) } & \multirow[b]{2}{*}{6} & \multirow[b]{2}{*}{7} \\
\hline & 1 & 2 & 3 & 4 & 5 & & \\
\hline \multirow[t]{2}{*}{ Po } & \multirow{2}{*}{219.33} & 11.75 & 138.03 & & & & \\
\hline & & $\mathrm{a}$ & $\mathrm{a}$ & $13.27 \mathrm{a}$ & $4.43 \mathrm{a}$ & $2426.67 \mathrm{a}$ & $178.33 \mathrm{a}$ \\
\hline \multirow[t]{2}{*}{ P1DPP } & \multirow{2}{*}{238.58} & 12.17 & 144.53 & & & & \\
\hline & & $\mathrm{a}$ & $\mathrm{a}$ & $13.48 \mathrm{a}$ & $4.37 \mathrm{a}$ & $2960.33 \mathrm{~b}$ & $205.60 \mathrm{~b}$ \\
\hline \multirow[t]{2}{*}{ P2DPP } & \multirow{2}{*}{240.25} & 12.50 & 161.48 & & & & \\
\hline & & b & b & $13.77 \mathrm{a}$ & $4.53 \mathrm{a}$ & $2982.50 \mathrm{~b}$ & $206.03 \mathrm{~b}$ \\
\hline \multirow{2}{*}{ P3DPP } & \multirow{2}{*}{224.92} & 12.33 & 160.29 & & & & \\
\hline & & $\mathrm{a}$ & b & $13.98 \mathrm{a}$ & $4.53 \mathrm{a}$ & $3170.17 \mathrm{~b}$ & $205.63 \mathrm{~b}$ \\
\hline P4DPP & 249.83 & $\begin{array}{c}12.58 \\
h\end{array}$ & 163.94 & 1402 & $456 a$ & $208633 \mathrm{~h}$ & $20560 \mathrm{~h}$ \\
\hline \multirow[t]{2}{*}{ P5DPP } & \multirow{2}{*}{238.58} & 12.42 & 170.44 & $17.02 \mathrm{a}$ & & 2300.00 & \\
\hline & & $\mathrm{b}$ & $\mathrm{b}$ & $14.11 \mathrm{a}$ & $4.60 \mathrm{a}$ & $3159.33 b$ & $205.00 \mathrm{~b}$ \\
\hline \multirow[t]{2}{*}{ P6DPP } & \multirow{2}{*}{239.58} & 12.50 & 172.09 & & & & \\
\hline & & $\mathrm{b}$ & $\mathrm{b}$ & $14.15 \mathrm{a}$ & $4.66 \mathrm{~b}$ & $3023.17 \mathrm{~b}$ & $208.10 \mathrm{~b}$ \\
\hline \multirow[t]{2}{*}{ P7DPP } & \multirow{2}{*}{255.92} & 13.00 & 172.09 & & & & \\
\hline & & $\mathrm{b}$ & $\mathrm{b}$ & $14.15 \mathrm{a}$ & $4.66 \mathrm{~b}$ & $\begin{array}{c}3481.33 \mathrm{~b} \\
(43.46 \\
\%)^{* *)}\end{array}$ & $213.07 \mathrm{~b}$ \\
\hline P1TPP & 231.67 & 11.92 & 161.33 & $14.05 \mathrm{a}$ & $4.54 \mathrm{a}$ & $3212.83 \mathrm{~b}$ & $215.33 b$ \\
\hline
\end{tabular}




\begin{tabular}{|c|c|c|c|c|c|c|c|}
\hline \multirow{3}{*}{$\begin{array}{l}\text { P2TPP } \\
\text { P3TPP }\end{array}$} & & $\mathbf{a}$ & U & & & & \\
\hline & 49.83 & $\begin{array}{c}12.17 \\
\mathrm{a}\end{array}$ & $\begin{array}{c}172.15 \\
b\end{array}$ & $14.11 \mathrm{a}$ & $4.63 \mathrm{~b}$ & $3221.17 \mathrm{~b}$ & $211.93 b$ \\
\hline & 247.75 & $\begin{array}{c}12.42 \\
b\end{array}$ & $\begin{array}{c}172.35 \\
b\end{array}$ & $14.15 \mathrm{a}$ & $4.63 \mathrm{~b}$ & $3230.67 \mathrm{~b}$ & $215.23 \mathrm{~b}$ \\
\hline P4TPP & 230.83 & $\begin{array}{c}12.08 \\
\mathrm{a}\end{array}$ & $\begin{array}{c}172.51 \\
b\end{array}$ & $14.27 \mathrm{a}$ & $4.65 \mathrm{~b}$ & $3419.67 \mathrm{~b}$ & $218.37 \mathrm{~b}$ \\
\hline P5TPP & 239.58 & $\begin{array}{c}12.58 \\
b\end{array}$ & $\begin{array}{c}179.67 \\
b\end{array}$ & $14.49 \mathrm{~b}$ & $4.67 \mathrm{~b}$ & $3451.33 \mathrm{~b}$ & $219.67 \mathrm{~b}$ \\
\hline P6TPP & 237.67 & $\begin{array}{c}12.50 \\
b\end{array}$ & $\begin{array}{c}173.36 \\
b\end{array}$ & $15.17 \mathrm{~b}$ & $4.72 \mathrm{~b}$ & $3451.00 \mathrm{~b}$ & $221.03 b$ \\
\hline P7TPP & 249.83 & $\begin{array}{c}13.17 \\
b\end{array}$ & $\begin{array}{c}194.93 \\
\text { b }\end{array}$ & $15.15 b$ & $4.72 \mathrm{~b}$ & $\begin{array}{c}3878.17 \mathrm{~b} \\
(79.21 \\
\%)^{* *)}\end{array}$ & $230.53 \mathrm{~b}$ \\
\hline Gumarang & 240.75 & $\begin{array}{c}14.25 \\
b\end{array}$ & $\begin{array}{c}165.10 \\
\mathrm{~b}\end{array}$ & $14.23 \mathrm{a}$ & $4.40 \mathrm{a}$ & $3394.17 \mathrm{~b}$ & $212.40 \mathrm{l}$ \\
\hline & & 0.58 & 21.92 & 1.18 & 0.17 & 463.05 & 12.79 \\
\hline
\end{tabular}

Keterangan: *). Angka-angka yang diikuti oleh huruf sama pada kolom sama tidak berbeda nyata dibanding dengan populasi awal dengan uji $\mathrm{BNT}_{0.05}$. 1 . Tinggi tanaman $(\mathrm{cm}) ; 2 . J u m l a h$ daun per tanaman (helai); 3. Bobot tongkol kering panen per tanaman (g); 4. Panjang tongkol (cm); 5. Diameter tongkol $(\mathrm{cm})$; 6.Bobot biji kering pipil per plot $(\mathrm{g})$; 7. Bobot 1.000 butir biji $(\mathrm{g})$; dan **) Persentase kenaikan dibanding populasi awal (Po).

Pada Tabel 3 terlihat bahwa rata-rata daya hasil populasi hasil seleksi massa DPP siklus ketujuh lebih besar dibandingkan dengan populasi awal. Demikian pula untuk populasi siklus sebelumnya. Seleksi massa tanpa pengendalian penyerbukan, menyebabkan daya hasil lebih tinggi sejak siklus pertama hingga siklus ketujuh. Daya hasil populasi awal, siklus ketujuh dengan cara DPP dan siklus ketujuh dengan cara TPP berturut-turut sebesar 2426.67 g. plot $^{-1}\left(5.056\right.$ t.ha $\left.^{-1}\right), 3481.33$ g. plot $^{-1}\left(7.253\right.$ t.ha $\left.{ }^{-1}\right)$ dan 3878.17 g. plot ${ }^{-1}$ $\left(8.080\right.$ t.ha $\left.^{-1}\right)$. Histogram dari seluruh populasi disajikan pada Gambar 2 .

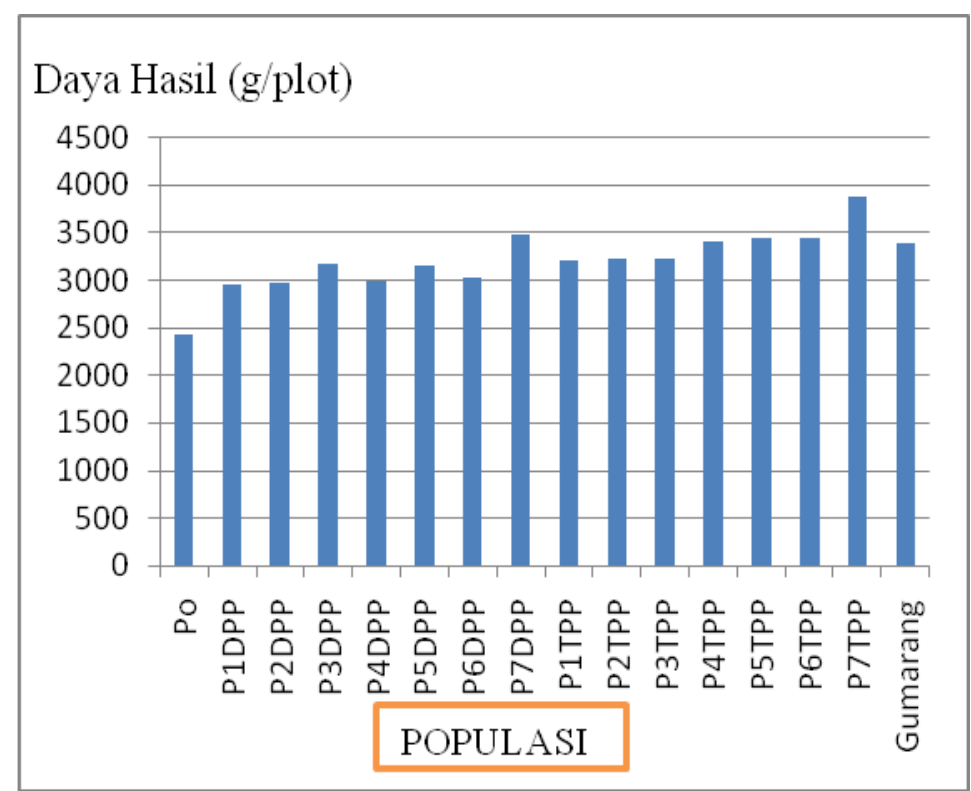

Gambar 2. Histogram daya hasil (g/plot) dengan macam populasi. 
Pada Tabel 4 terlihat, bahwa seluruh sifat yang diamati berkorelasi positif nyata dengan daya hasil; namun tingkat keeratan hubungan yang berbeda. Bobot tongkol kering panen per tanaman dan bobot 1.000 butir biji memiliki tingkat keeratan lebih tinggi dibanding tinggi tanaman dan jumlah daun berturut-turut $0.761,0.764,0.363$ dan 0.395 .

Tabel 4. Nilai koefisien korelasi antar sifat dengan daya hasil

\begin{tabular}{lc}
\hline Sifat-sifat yang diamati & \multicolumn{2}{c}{$\begin{array}{c}\text { Nilai koefisien korelasi dengan } \\
\text { daya hasil }\end{array}$} \\
\hline Tinggi tanaman $(\mathrm{cm})$ & $0.363 *)$ \\
Jumlah daun per tanaman (helai) & $\left.0.395^{*}\right)$ \\
Bobot tongkol kering panen per & $\left.0.761^{*}\right)$ \\
tanaman $(\mathrm{g})$ & \\
Panjang tongkol (cm) & $\left.0.594^{*}\right)$ \\
Diameter tongkol (cm) & $\left.0.566^{*}\right)$ \\
Bobot 1.000 butir biji (g) & $\left.0.764^{*}\right)$ \\
\hline Keterangan: $*$ ), Berbeda nyata pada taraf nyata 5 persen.
\end{tabular}

\section{Pembahasan}

Seleksi menyebabkan peningkatan frekuensi gen dan frekuensi genotip untuk sifat yang diseleksi dan sifat yang diperbaiki. Kedua hal tersebut dapat dilihat adanya peningkatan rerata populasi. Selisih populasi hasil seleksi dengan populasi awal disebut respon seleksi (Soemartono, et al., 1992; Basuki, 2005). Dalam seleksi ini, sifat yang diperbaiki adalah daya hasil (bobot biji kering pipil per plot). Sifat tersebut diperbaiki secara tidak langsung melalui tinggi tanaman dan jumlah daun per tanaman untuk seleksi massa dengan pengendalian penyerbukan dan didasarkan bobot tongkol kering panen untuk seleksi tidak langsung tanpa pengendalian penyerbukan. Respon seleksi dapat dilihat dari rerata populasi setelah dilakukan beberapa siklus dikurangi dengan populasi awal.

Rata-rata respon per siklus seleksi massa secara tidak langsung tanpa pengendalian penyerbukan terhadap daya hasil melalui bobot tongkol kering panen bersifat linear yang nyata. Demikian pula seleksi massa tidak langsung dengan pengendalian penyerbukan, melalui tinggi tanaman dan jumlah daun. Hal ini berarti rata rata kemajuan seleksi kedua cara seleksi massa tersebut, berdampak besar terhadap perubahan rerata populasi. Sudika, et al. (2018) memperoleh, bahwa kemajuan seleksi hingga siklus kelima dengan teknik pengendalian penyerbukan untuk daya hasil dan biomas segar bersifat linear yang nyata. Adrienne, et al. (2015) juga memperoleh, bahwa kemajuan seleksi bersifat linear yang nyata untuk ukuran dan bentuk tongkol pada jagung manis bersari bebas. Kemajuan seleksi yang bersifat linear nyata, dapat terjadi akibat keragaman genetik, sifat yang diseleksi besar dan memiliki nilai korelasi genetik tinggi terhadap sifat yang diperbaiki. Alasan tersebut sesuai dengan pendapat Basuki (2005), bahwa sifat yang memiliki keragaman genetik tinggi, maka akan diperoleh kemajuan seleksi yang besar. Elfiani (2015) juga memperoleh, bahwa tinggi tanaman lebih efektif untuk menaikkan komponen hasil (panjang tongkol dan diameter tongkol) pada jagung manis. Idris, et al. (2018) memperoleh hal yang berlawanan akibat penanaman jagung Lokal Kebo ditanam secara tumpangsari dengan kacang tanah. Selain itu, kemungkinan disebabkan oleh hubungan yang erat antara daya hasil dengan tinggi tanaman 
dan jumlah daun (lihat Tabel 4). Al-Naggar, et al. (2016) memperoleh hal yang sama, bahwa terjadi korelasi yang sangat erat antara daya hasil dengan tinggi tanaman pada jagung hibrida.

Selain keragaman genetik yang tinggi, kemajuan seleksi secara tidak langsung juga ditentukan oleh heritabilitas sifat yang diseleksi dan tingkat keeratan hubungan sifat yang diseleksi dengan daya hasil (Soemartono, et al., 1992). Pada Tabel 2 terlihat, bahwa heritabilitas sifat yang diseleksi (jumlah daun per tanaman) tergolong tinggi yaitu sebesar 73.12 persen dan bobot tongkol kering panen tergolong sedang yaitu sebesar 40.02 persen. Daya hasil memiliki heritabilitas tergolong sedang sebesar 49.75 persen. Nilai heritabilitas sebesar tersebut memungkinkan diperoleh kemajuan seleksi cukup besar untuk daya hasil.

Respon seleksi untuk seleksi massa secara tidak langsung dengan pengendalian penyerbukan, nilainya lebih kecil dibanding seleksi secara tidak langsung tanpa pengendalian penyerbukan untuk daya hasil. Hal ini dapat terjadi karena bobot tongkol kering panen memiliki hubungan yang lebih erat dengan daya hasil dibanding tinggi tanaman dan jumlah daun yang digunakan sebagai kriteria seleksi dengan pengendalian penyerbukan (lihat Tabel 4). Hal ini berlawanan dengan hasil penelitian Sutresna (2010), bahwa kemajuan seleksi dengan pengendalian penyerbukan terhadap hasil (berat biji kering pipil per plot) sebesar $2.07 \mathrm{~kg}$ (44.04\%) selama tiga siklus; lebih tinggi dibanding tanpa pengendalian penyerbukan, yaitu sebesar $1.67 \mathrm{~kg}(33.99 \%)$. Seleksi tanpa pengendalian penyerbukan menggunakan criteria seleksi berat biji kering pipil per tanaman; berarti seleksi dilakukan secara langsung.

Peningkatan daya hasil akibat seleksi massa tidak langsung selama tujuh siklus dengan pengendalian penyerbukan dan tanpa pengendalian, cukup besar berturut-turut sebesar 43.46 persen dan 79.21 persen. Daya hasil kedua populasi hasil seleksi siklus ketujuh lebih tinggi dibanding populasi awal. Daya hasil P7DPP, P7TPP dan populasi awal berturutturut sebesar $3481.33 \mathrm{~g} /$ plot (8.080 t/ha), 3878.17 (7.253 t/ha) dan $2426.67 \mathrm{~g} /$ plot (5.056 t/ha). Peningkatan tersebut terjadi karena seleksi yang dilakukan selama tujuh siklus, menyebabkan peningkatan frekuensi gen dan frekuensi genotip daya hasil. Hal ini sesuai pendapat Soemartono, et al. (1992), bahwa seleksi menyebabkan perubahan frekuensi gen dan frekuensi genotip yang dapat dilihat dari perubahan rerata populasi.

\section{KESIMPULAN}

Berdasarkan hasil dan pembahasan, maka disimpulkan sebagai berikut:

1. Respon seleksi massa secara tidak langsung dengan pengendalian penyerbukan dan tanpa pengendalian bersifat linear yang nyata untuk daya hasil .

2. Terjadi peningkatan daya hasil sebesar 43.46 persen setelah dilakukan tujuh siklus seleksi tidak langsung dengan pengendalian penyerbukan dan 79.21 persen dengan tanpa pengendalian penyerbukan dibanding populasi awal.

3. Kegiatan seleksi massa tidak langsung baik dengan pengendalian maupun tanpa pengendalian penyerbukan siklus berikutnya masih dapat dilanjutkan agar terjadi peningkatan daya hasil yang lebih besar dibanding populasi awal.

\section{Ucapan Terima Kasih}

Tim peneliti mengucapkan terima kasih yang sebesar-besarnya kepada Direktorat Riset dan Pengabdian Kepada Masyarakat, Direktorat Jenderal Penguatan Riset dan 
Pengembangan, Kementerian Riset, Teknologi dan Dikti RI, atas dana yang telah diberikan melalui skema PTUPT, sehingga penelitian dapat terlaksana.

\section{DAFTAR PUSTAKA}

Al-Naggar, A.M.M., M. M. M. Atta, M. A. Ahmed and A. S. M. Younis. 2016. Direct vs Indirect Selection for Maize (Zea mays L.) Tolerance to High Plant Density Combined with Water Stress at Flowering. Journal of Applied Life Sciences International 7(4): 117.

Adrienne C., Shelton and William F. Tracy. 2015. Recurrent Selection and Participatory Plant Breeding for Improvement of Two Organic Open-Pollinated Sweet Corn (Zea mays L.) Populations . Sustainability 7: $5139-5152$.

Basuki, N. 2005. Genetika Kuantitatif. Fakultas Pertanian Universitas Brawijaya, Malang.

Elfiani. 2015. Efektivitas Metode Seleksi Massa Populasi Bersari Bebas Jagung Manis.Jurnal Dinamika Pertanian Vol.XXX no 3 (209 - 214).

Idris dan Uyek Malik Yakop . 2018. Kemajuan Seleksi Massa Pada Jagung Kultivar Lokal Kebo Setelah Lima Siklus Seleksi Dalam Pertanaman Tumpangsari Dengan Kacang Tanah. Crop Agro vol4 no 2: 37-42

Indriani, F.C. dan Mejaya. 2012. Toleransi Genotipe Jagung Biji Putih terhadap Cekaman Kekeringan. Hal. 411 - 420. Prosiding Seminar Nasional Pusat Penelitian dan Pengembangan Tanaman Pangan, Badan Penelitian dan Pengembangan Pertanian.

Little TM.And F. J. Hills. 1972. Statistical Methods in Agricultural Research.Univ of California, Davis. California.

Mejaya, M. J., Azrai dan R. N. Iriany. 2010. Pembentukan Varietas Unggul Jagung Bersari Bebas. Hal. 55 - 73. Dalam Jagung: Teknik Produksi dan Pengembangan. Litbang Deptan.

Rizqi Fadillah Romadhona, Panjisakti Basunanda, Rudi Hari Murti. 2014. Perbandingan Kemajuan Genetis Seleksi Massa dan Tongkol-ke-Baris pada Populasi Generasi Ketiga Persarian Bebas Jagung Hibrida (Zea mays L.). Jurnal Ilmiah Vegetalika vol 3 no.2.

Soemartono, Nasrullah dan H. Hartiko. 1992. Genetika Kuantitatif dan Bioteknologi Tanaman. PAU Bioteknologi UGM, Yogyakarta. $374 \mathrm{~h}$.

Sudika, Arya Parwata dan Soemeinaboedhy. 2018. Kajian Dua Teknik Seleksi Massa Guna Perbaikan Daya Hasil dan Stay-Green pada Tanaman Jagung di Lahan Kering. Prosiding Seminar Nasional Fakultas Pertanian Universitas Muhammadyah Mataram. hal. $100-106$.

Sutresna. 2010. Pengaruh Seleksi Massa Terhadap Kemajuan Genetik Populasi Tanaman Jagung (Zea mays L.). Agroteksos 20 (2-3): 112 - 118.

Stainfield, W.D. 1991. Theory and Problems of Genetics. Mc. Graw. Hills. Inc9. 